\title{
Hasta ve Hemşirelerin Perspektifinden İyi Hemşire: Nitel Bir Çalışma*
}

\author{
Patients' and Nurses' Perspectives on "A Good Nurse": A Qualitative Study \\ İpek Köse Tosunözi, Meltem Akbaşii, Gürsel Öztunçiii
}

ï̈ğr. Gör., Hatay Mustafa Kemal Üniversitesi Sağlık Bilimleri Fakültesi Hemşirelik Bölümü, https://orcid.org/0000-0003-2055-6260 iiDr.Öğr.Üyesi, Çukurova Üniversitesi Sağlık Bilimleri Fakültesi Ebelik Bölümü, https://orcid.org/0000-0002-5845-0552

iiiProf.Dr., Girne Üniversitesi Sağlık Bilimleri Fakültesi Hemşirelik Bölümü, https://orcid.org/0000-0003-1972-1257

öz

Amaç: Bu çalışmanın amacı, hasta ve hemşirelerin perspektifinden iyi bir hemşirenin kim olduğuna ilişkin görüşleri belirlemektir. Gereç ve Yöntem: Araştırma, nitel bir durum araştırması olarak tasarlandı. Araştırmanın örneklemini on bir hemşire ve sekiz hasta oluşturdu. Veriler, yarı yapılandırılmış görüşme formu ile yüz yüze görüşülerek toplandı. Verilerin analizinde içerik analiz yöntemi kullanılmıştır.

Bulgular: Hemşirelere göre iyi hemşire özellikleri "gelişim ve değişime açıklık”, "mesleki yetkinlik", "iletişim”, "mesleki bilinç ve sevgi" ve "kişilik özellikleri" kategorilerinden oluşmuştur. Mesleki yetkinlik kategorisi için bilgi, beceri, deneyim ve uygun bakım; kişilik özellikleri kategorisi için öz disiplin ve insancıl özellikler alt kategorileri belirlenmiştir. Hastalara göre iyi hemşire özellikleri "iletişim", "mesleki yetkinlik", "mesleği sevme" ve "kişilik özellikleri” kategorilerinden oluşmuştur. Altı hemşirenin kendisini iyi bir hemşire olarak görmediği belirlenmiştir. Hemşirelerin kendilerini iyi bir hemşire olarak görmelerini engelleyen faktörler "bireysel" ve "sistemsel" nedenler olarak belirlenmiştir. Bireysel nedenleri yetersiz mesleki bilgi ve beceri, mesleki değişiklikleri takip edememe, olaylara duygusal yaklaşma ve sorunlarla baş edememe; sistemsel nedenleri ise hasta sayısı ile iş yükünün fazla ve hemşire sayısının az olması oluşturmuştur.

Sonuç: Hemşirelerin idealize ettikleri ve kendilerinin sahip olduklarını düşündükleri iyi hemşire özellikleri ile hasta ve hemşirelerin iyi bir hemşirenin özeliklerine yönelik görüşlerinin benzer ancak bazı açılardan farklılık gösterdiği belirlenmiştir.

Anahtar Kelimler: Özellik, İyi hemşire, Hemşire, Hasta, Algılama.

ABSTRACT
Aim: The aim of this study is to identify patients' and nurses' perspectives about who is a good nurse.

Materials and Methods: This was a qualitative study. The study sample consisted of eleven nurses and eight patients. Data were collected with a semi-structured interview form. Data were analyzed using content analysis methods.

Findings: According to nurses, good nurse characteristics consisted of "openness to development and change", "professional competence", "communication", "professional awareness and love" and "personality traits" categories. It was determined knowledge, skill, experience and appropriate care subcategories for the professional competence category; "self-discipline" and "humanitarian traits" subcategories for the personality traits category. According to patients, good nurse characteristics consisted of "communication", "professional competence", "liking the profession" and "personality traits". It was determined that six nurses did not see themselves as a good nurse. The factors that prevent nurses from seeing themselves as good nurses were identified as "individual" and "systemic" reasons. Individual reasons were insufficient professional knowledge and skills, inability to follow professional changes, emotional approach to events and inability to cope with problems; the systemic reasons were high number of patients, heavy workload and the low number of nurses.

Conclusions: It was determined that the good nurses' characteristics that nurses idealize and think they have and the patients and nurses' opinions about a good nurse's characteristics were similar but differed in some aspects.

Key words: Character, Good nurse, Nurse, Patient, Perceptions.

*Lokman Hekim Dergisi, 2021; 11 (2): 319-330

DOI: $10.31020 /$ mutftd.868127

e-ISSN: 1309-8004, ISSN 1309-761X

Geliş Tarihi - Received: 25 Ocak 2021; Kabul Tarihi - Accepted: 17 Mart 2021

iletişim - Correspondence Author: Ipek Köse Tosunöz <kosepek@hotmail.com>

Etik Onay: Çukurova Üniversitesi Tıp Fakültesi Girişimsel Olmayan Klinik Araştırmalar Etik kurulu (14 Şubat 2020, karar no: 96/89) 


\section{Giriş}

Günümüzde sağıık bakım sisteminin karmaşıklaşan ve toplumun değişen yapısı, hemşireliğin modern bir mesleğe dönüşmesini zorunlu tutmuş ve belirli bir bilgi, beceri ve tutuma sahip profesyonel hemşirelere olan ihtiyacı arttırmıştır., ${ }^{1,2}$ Yirminci yüzyılın başlarında hemşirelik, hasta bireylere hizmet veren, dinsel bir görevi yerine getiren ve hekim yardımcısı bir iş olarak görülürken, günümüzde bilimsel yaklaşımlarla değişimler geçirerek uygulama alanları, rol ve sorumlulukları genişlemiş ve bağımlı, hastalığa odaklanmış bir işten, özerk ve sağlığa odaklanmış bir mesleğe dönüşmüştür. ${ }^{3,4}$ Meslekleşme süreci içerisinde hemşirelerin birey, aile ve toplumun değişen bakım gereksinimlerini karşılayabilen iyi hemşireler olabilmeleri için mesleki yetkinliklerinin yanı sıra bazı kişilik özelliklerine sahip olmaları gerektiği vurgulanmaktadır. ${ }^{1,5}$ Hemşirelerden mesleki bilgilerini ve becerilerini geliştirmelerinin yanı sıra, araştırma yapmaları, mesleki örgütlere ve politik aktivitelere katılmaları, yenilikçi yaklaşımlar sergilemeleri, iyi kişilik özelliklerine, ahlaki ve etik değerlere sahip olmaları beklenmektedir. ${ }^{1-5}$

İyi hemşire kavramı sosyal, kültürel ve politik faktörlerden etkilenen dinamik bir kavramdır. ${ }^{6}$ Literatürde iyi hemşire kavramı ve bu kavramın hastalar ve hemşireler tarafından nasıl yorumlandığı açıkça belirtilmemektedir. ${ }^{1-5}$ İyi hemşirenin kavram olarak içeriğinin tanımlanmamış olması, bu kavramın eğitimde ve uygulamada kullanımını engellemektedir. İyi bir hemşirenin sahip olması gereken mesleki ve kişilik özelliklerinin belirlenmesi, bu özelliklerin mesleki eğitimleri sırasında öğrencilere aktarılabilmesi ve uygulama alanlarında hemşirelerin bu özellikler açısından değerlendirilebilmesi için önemlidir., ${ }^{1,2}$ İyi hemşirenin özelliklerini belirlemek amacıyla yapılan çalışmalarda çoğunlukla hemşirelik becerileri ve hastaların hemşirelik bakımının kalitesine ilişkin algıları araştırımıştır. ${ }^{6,7}$ Farklı sağlık deneyimleri ve rolleri olan hemşire ve hastaların iyi hemşireye yönelik algıları hemşirelik bakımının kalitesini ve hasta memnuniyetini etkilemektedir., ${ }^{2,7}$ Sağ ıı bakım sisteminin merkezinde olan hemşire ve hastaların iyi hemşireye ilişkin görüşlerinin belirlenmesi, mesleki eğitimden uygulamaya kadar her alanda hemşirelikte profesyonelliğin sağlanmasına ve sürdürülmesine önemli katkı sağlayacaktır. ${ }^{1}$ Aynı zamanda hastaların ve hemşirelerin iyi bir hemşireye ilişkin algıları araştırılarak, hemşirelerin toplumun değişen ihtiyaçlarını karşılayabilecek nitelikleri belirlenebilecektir. ${ }^{2}$ Smith ve Godfrey iyi bir hemşirenin kim olduğunu belirlemek amacıyla daha fazla araştırma yapılması gerektiği üzerinde durmuştur. ${ }^{8}$ Bu bilgiler ışığında, bu çalışmada hemşire ve hastaların iyi bir hemşirenin kim olduğuna ilişkin görüşlerini belirlemek amaçlanmıştır.

\section{Gereç ve Yöntem}

\section{Araştırma Deseni}

Araştırma nitel bir durum çalışması olarak yürütülmüştür. Araştırma nitel araştırma yöntemlerinden görüşme yöntemi ile yapılmıştır.

\section{Evren ve Örneklem}

Araştırma grubundaki hemşire ve hastalar, amaçlı örnekleme yöntemi kullanılarak belirlenmiştir. Araştırmanın katılımcıları, bir üniversite hastanesinde çalışan hemşireler ve aynı hastanede yatarak tedavi gören hastalar arasından seçilmiştir. Araştırmaya bir üniversite hastanesinin servis, yoğun bakım, acil, ameliyathane ve idari birimlerinde çalışan, çalışmaya katılmaya gönüllü 11 hemşire; araştırmaya katılan hemşirelerin çalıştıkları birimlerde en az 24 saat yatarak tedavi gören ve bakım alan, iletişim kurabilen, 18 yaş ve üstü, araştırmaya katılmaya gönüllü sekiz hasta dahil edilmiştir.

Araştırmada amaçlı örnekleme yöntemlerinden maksimum çeşitlilik kullanılmıştır. Araştırmada farklı birimlerdeki ve pozisyonlardaki hemşirelerin ve farklı birimlerde yatan hastaların görüşlerinin temsil edilmesi amaçlanmıştır. ${ }^{9}$ Hastanede yer alan birimler; servis, yoğun bakım, acil, ameliyathane ve idari 
birimler olarak gruplandırılmıştır. Bu araştırmanın örneklemi kapsamında her birimden en az bir hemşireyle görüşme yapılması hedeflenmiştir.

\section{Verilerin Toplanması}

Araştırma verileri, yüz yüze yapılan derinlemesine görüşme tekniği ile toplanmıştır. Katılımcılara araştırmanın kapsamı ve amaçları ile ilgili bilgi verilmiştir. Hemşireler ile görüşmeler hemşire odasında, hastalar ile hasta odalarında yapılmıştır. Katılımcılardan görüşmeleri kayıt cihazına kayıt etmek üzere izin alınmış ve görüşmeler sırasında ses kayıt cihazından yararlanılmıştır. Kayıtlar 14 sayfalık yazılı metin haline getirilmiştir. Verilerin tekrarlamaya başlaması üzerine veri toplama sonlandırılmıştır.

Veriler, tanıtıcı bilgi formu ve yarı yapılandırılmış görüşme formu ile toplanmıştır. Tanıtıcı bilgi formunun doldurulması ortalama 2-3 dakika, hemşirelerle görüşmeler 30-35 dakika ve hastalar ile görüşmeler 20-25 dakika sürmüştür. Tanıtıcı bilgi formu hemşirelerin cinsiyet, yaş, eğitim durumu, çalışılan klinik ve çalışma süresine ilişkin bilgileri; hastaların cinsiyet, yaş ve yattıkları kliniklere ilişkin bilgileri içermektedir. Yarı yapılandırılmış görüşme formunda hemşirelere iki açık uçlu, biri kapalı uçlu olmak üzere üç görüşme sorusu sorulmuştur. Hastalara bir açık uçlu soru sorulmuştur. Hemşirelere yönelik sorular "Size göre iyi hemşire kimdir? lyi bir hemşirenin sahip olması gereken özellikleri tanımlar mısınız?", "Size göre siz iyi bir hemşire misiniz?", "Size iyi bir hemşire olduğunuzu/olmadığınızı düşündürten özellikleriniz nelerdir?" şeklinde ve hastalara yönelik ise "Size göre iyi hemşire kimdir? lyi bir hemşirenin sahip olması gereken özellikleri tanımlar mısınız?" şeklinde oluşturuldu.

\section{Verilerin Değerlendirilmesi}

Veriler toplandıktan sonra analizinde, içerik analizi kullanılmıştır. İçerik analizinde veriler kodlanarak kategorileştirilmiş, temalar bulunmuş, veriler kodlara ve temalara göre düzenlenmiş, bulgular yorumlanmıştır. Analiz iki araştırmacı tarafından ayrı olarak yapıldıktan sonra yapılan kodlamalar karşılaştırıımış ve farklı düşünülen kodlamalarda uzlaşılmıştır. Bulguların sunumunda doğrudan alıntılar verilmiştir. Katılımcılardan alıntı yaparken "Hemşire" ya da "Hasta" olarak belirtilmiş ve katılımcılara verilen numaralar alıntıların sonuna eklenmiştir (örneğin Hemşire 1 veya Hasta 1 gibi).

\section{Etik Onay}

Araştırma öncesinde Çukurova Üniversitesi Tıp Fakültesi Girişimsel Olmayan Klinik Araştırmalar Etik kurulundan (14 Şubat 2020 tarih, 96/89 karar no) etik onay alınmıştır. Katılımcılara verdikleri bilgilerin yalnız bilimsel amaçla kullanılacağı, üçüncü şahıslarla paylaşılmayacağı ve istedikleri zaman çalışmadan ayrılabileceklerinin bilgisi verilmiş ve sözlü izinleri alınmıştır. Ses kayıtları dökümü yapıldıktan sonra silinmiştir. Veriler sunulurken isim kullanılmamıştır.

\section{Bulgular}

\section{Katılımcıların Özellikleri}

Araştırmaya dokuzu kadın, ikisi erkek olmak üzere 11 hemşire katılmıştır. Hemşirelerin yaşları 20-32 arasında ve çalışma süreleri 7 ay-8 yıl arasında değişmektedir. Hemşirelerden biri Sağlık Meslek Lisesi mezunu, beşi lisans mezunu ve beşi lisansüstü eğitim düzeyindedir. Hemşirelerin ikisi supervisör, altısı servis, biri acil, biri ameliyathane ve biri yoğun bakım hemşiresidir. Araştırmaya ikisi kadın, altısı erkek olmak üzere sekiz hasta katılmış olup hastaların yaşları 19-55 arasında değişmektedir. Araştırmaya katılan hastaların üçü Kulak Burun Boğaz Servisi, üçü Nefroloji ve ikisi Endokrin servislerinde yatmaktadır.

Çalışmada içerik analizine dayanarak elde edilen bulgular dört ana tema altında gruplandırımıştır. 


\section{Ana Tema 1. Hemşirelere Göre İyi Bir Hemşirenin Özellikleri}

Hemşirelerin iyi bir hemşirenin özelliklerine ilişkin görüşleri kodlanarak beş alt tema oluşturulmuştur.

\section{Alt Tema 1. Gelişim ve değişime açıklık}

Hemşireler iyi bir hemşirenin mesleği ile ilişkili yenilikleri takip eden ve değişimlere açık hemşireler olduklarını belirtmişlerdir. Bir hemşire;

"...yenilikleri takip eden ve değişime açık bir hemşire bana göre iyi bir hemşiredir. Kurumundaki servisindeki yeni ürünleri, uygulamaları bilir." (Hemşire 8)

başka bir katılımcı;

"Mesleğimizde değişim şart. Hastaların ihtiyaçları, sağlık sorunları değişirken hemşire bu değişimlerden uzak kalmamalı, zorunlu olarak değişmek zorunda bence." (Hemşire 3) şeklindeki ifadesi ile değişimin önemine ve gerekliliğine dikkat çekmiştir.

\section{Alt tema 2. Mesleki yetkinlik}

Mesleki yetkinlik ile ilişkili ifadeleri "bilgi", "beceri", "deneyim" ve "uygun bakım" alt kategorileri oluşturmuştur.

Bilgi kategorisinde hemşireler iyi bir hemşire için mesleki bilginin önemine;

"lyi ve yeterli bir bilgi birikimine sahip, alanında tecrübeli kişidir." (Hemşire 11) ifadesi ile dikkat çekmiştir.

Beceri kategorisinde bir hemşire meslekte çeşitli problemler ile karşılaştıklarını ve iyi bir hemşirenin bu problemleri çözebildiğine ilişkin görüşünü;

"Birçok sorunla karşılaşabiliyoruz. İyi bir hemşire iseniz bu sorunların üstesinden gelmeniz beklenir." (Hemşire 5)

ifadesi ile belirtmiştir.

Deneyim kategorisinde iyi bir hemşire olabilmek için deneyimin önemi şu şekilde vurgulanmıştır:

"...Tabi tecrübe ve deneyim de önemli" (Hemşire 4).

Uygun bakım kategorisinde hemşirelerin bütüncül ve hasta gereksinimlerine uygun bakım verme özellikleri öne çıkmaktadır. Hemşirelerden biri bütüncül bakım vermeye ilişkin görüşünü;

"Hasta odaklı yaklaşan ve hastaya bütüncül olarak bakıp bütüncül bakım verendir aynı zamanda." (Hemşire 10)

şeklinde belirtmiştir.

Bir hemşire iyi bir hemşirenin hasta gereksinimlerine uygun bakım verdiğini

"Hastanın ihtiyaçlarına göre, gereksinimlerine göre bakımını planlayan." (Hemşire 4) ifadesi ile belirtmiştir.

\section{Alt Tema 3. iletişim}

Hemşireler iyi bir hemşirenin iletişim ve empati kurma becerisine sahip olduğunu belirtmişlerdir. Bu konuda bir hemşire;

"Bana göre hastaları ile iletişime girebilen ve aynı zamanda empati de kurabilen hemşiredir." (Hemşire 1), 
başka bir hemşire ise;

"Iyi hemşire empati yapabilen, hastalar ile iletişimi iyi olan hemşiredir. lyi bir hemşire hastaları ile iletişime rahat geçebilir." (Hemşire 2)

şeklinde görüşünü paylaşmıştır. Başka bir hemşire;

"... Bakım ekip işidir. Hastalara daha iyi bakım verebilmek için çalışma arkadaşları ile anlaşabilmeli. iletişim sorunu yaşayınca hastanın bakımı aksayabilir." (Hemşire 4) şeklinde ifade ederek ekip içindeki iletişimin önemini vurgulamıştır.

\section{Alt tema 4. Mesleki bilinç ve sevgi}

Bu kategori hemşirelerin, iyi bir hemşirede olması gerektiğini düşündükleri mesleki bilince sahip olma, mesleği severek yapma, mesleği sevme ve mesleki sorumluluklarının bilincinde olma özelliklerine ilişkin görüşleri içermiştir. Bu bağlamda bir hemşire;

"Görev ve sorumluluk bilinci olan hemşiredir. Bu meslekte sorumluluk çok önemli. Sonuçta insan hayatının sorumluluğu üzerimizde." (Hemşire 9),

bir diğer hemşire;

“...Bazen mesleğini severek de iyi yapan vardır, sevmeyerek de iyi yapan vardır. Bu kişinin kendi potansiyeline bağlı diye düşünüyorum. Önemli olan işini severek iyi yapabilmek. lyi bir hemşirenin farkı da bu noktada bence, işini severek yapmakta." (Hemşire 3)

ifadesiyle görüşünü paylaşmıştır.

\section{Alt tema 5. Kişilik özellikleri}

Kişilik özellikleri kategorisi, öz disiplin ve insancı özellikler olarak iki alt kategoride ele alınmıştır. Öz disiplin özellikleri açısından hemşireler iyi bir hemşirenin prensipli, planlı, düzenli, dikkatli ve disiplinli olması gerektiğini belirtmiştir. Bir hemşire bu konudaki görüşünü;

"Önce planlı olmalı hemşire. Prensipli, düzenli olmalıdır. Her şeye saatinde yetişmeye çalışmalıdır. Bir de dikkatli olmalı, her konuda. Hasta takiplerinde, bakım ve uygulamalarında uyanık olmalı." (Hemşire 8)

şeklinde belirtmiştir. İnsancıl özellikler açısından hemşireler iyi bir hemşirenin vicdanlı, merhametli, güvenilir, hastalara eşit davranan ve içinde insan sevgisi barındıran hemşireler olduklarını belirtmiştir. Hemşirelerin bu konudaki bazı ifadeleri aşağıda yer almaktadır.

"iyi bir hemşire vicdan sahibidir. Merhametlidir. Insan ile çalışıyorsun sonuçta. Bu mesleği seçti isek vicdan sahibi olmalıyız." (Hemşire 4)

"Dil, din, ırk ayırt etmeden tedavisini yapandır. Herkese insan olmaları nedeniyle eşit davranandır." (Hemşire 5)

"...Bunların yanı sıra iyi bir hemşirenin içinde insan sevgisi de olmalı. İçinde insan sevgisi olmayan bu mesleği yapamaz." (Hemşire 7)

\section{Ana Tema 2. Hemşirelerin sahip olduklarını düşündükleri iyi hemşire özellikleri}

Beş hemşire kendisinin iyi bir hemşire olduğunu belirtmiştir. İyi bir hemşire olduklarını düşünen hemşirelerin sahip olduklarını düşündükleri iyi hemşire özellikleri dört tema altında toplanmıştır. 


\section{Alt tema 1. Gelişim ve değişime açıklık}

Hemşireler yenilikleri takip etmelerinin, bunları uygulamalarına yansıtmanın ve bilgilerini güncellemelerinin sahip oldukları iyi hemşire özellikleri olduğunu belirtmişlerdir. Bu konuda bir hemşire;

"Hemşirelik ile ilgili yenilikleri takip ediyorum. Bunları çalıştığım serviste uygulamaya çalışıyorum." (Hemşire 8)

ifadesiyle bu konudaki görüşünü belirtmiştir.

\section{Alt tema 2. Mesleki yetkinlik}

Hemşireler kendilerini iyi bir hemşire yapan özelliklerinin iyi bir mesleki bilgiye sahip olmaları, deneyimli olmaları, hasta memnuniyetini önemsemeleri, bütüncül, hasta isteklerine ve gereksinimlerine uygun bakım vermeleri olduğunu belirtmiştir. Bir hemşire hastanın sadece fizyolojik gereksinimlerine değil psikolojik gereksinimlerine de odaklandığını belirtmiştir. Bu konudaki bazı hemşire görüşleri aşağıda verilmiştir.

"Klinik deneyimi açısından donanımlı olduğumu düşünüyorum." (Hemşire 6)

"Hastanın memnuniyetine önem veriyorum. Hastan memnun ise iyi bir bakım vermişsin demektir bence." (Hemşire 10)

"Öncelikle hastalara bir bütün olarak yaklaşmak. Benim için iyi bir hemşire sadece bir organa, ya da hastalığa yönelmemeli. Bütüncül olarak düşünebildiğim ve bütüncül olarak bakım verdiğim için iyi bir hemşire olduğumu düşünüyorum. Çünkü başkaları için genellikle önemsenen hastalık olabiliyor. Ben sadece hastanın ameliyatının iyi geçmesine ya da vitallerinin iyi olmasına odaklanmıyorum. Hastanın psikolojik durumunu da düşünüp hasta ile iletişim kuruyorum, bunları anladıktan sonra hastalığa yöneliyorum, ona göre uygulama yapıyorum. Ondan dolayı iyi bir hemşire olduğumu düşünüyorum." (Hemşire 1)

"Hasta merkezli çalışmaya özen gösteriyorum. Hastanın ihtiyaçlarını göre bakım vermeye çalışıorum." (Hemşire 7)

\section{Alt tema 3. İletişim}

Hemşirelerin kendilerini iyi bir hemşire olarak nitelendirmelerinde hastalar ile iyi iletişim kurmalarının ve empati yapabilmelerinin etkili olduğu belirlenmiştir. Kendini iyi bir hemşire olarak nitelendiren hemşirelerden biri;

"Hastalarla iletişimim iyi." (Hemşire 4)

ifadesiyle, bir başka hemşire;

"...hastalarla iletişime rahat girebilmek, empati yapabilmek..." (Hemşire 2)

ifadesi ile bu konudaki görüşlerini belirtmişlerdir.

\section{Alt tema 4. Kişilik özellikleri}

Hemşirelerin sorumluluk sahibi ve kuralcı olmaları nedeni ile kendilerini iyi bir hemşire olarak nitelendirdikleri belirlenmiştir. Ayrıca sabırlı, güler yüzlü, saygılı ve hoşgörülü olma özellikleri de hemşirelerin kendilerini iyi bir hemşire yaptığını düşündükleri özellikler olduğu belirlenmiştir. Konu ile ilgili bazı ifadeler aşağıda verilmiştir.

"Ben sabırlı ve güler yüzlü olduğumu düşünüyorum." (Hemşire 4)

"Kuralcı bir hemşireyimdir. Kurallara mümkün olduğunca uyarım ve dışına çıkmam. Hem genel hastane kurallarında hem de hastaya yapılan bakım uygulamalarında." (Hemşire 2) 


\section{Ana Tema 3. Hemşirelerin kendilerini iyi bir hemşire olarak görmeme nedenleri}

Araştırmaya katılan hemşirelerin altısı kendini iyi bir hemşire olarak görmediğini belirtmiştir. Hemşirelerin kendilerini iyi bir hemşire olarak görmemelerine neden olan faktörler iki kategori altında toplanmıştır.

\section{Alt tema 1. Sistemsel nedenler}

Hemşireler hasta sayısı ile iş yükünün fazla ve hemşire sayısının az olması nedeni ile hastalara yeterince zaman ayıramadıklarını ve istendik bakımı veremediklerini belirtmiştir. Bir hemşire;

"Sayımızın az ve hasta sayısının fazla olması nedeni ile hastalar ile birebir ilgilenme zamanımız olmuyor. işs yoğunluğumuz çok fazla. Çok sirkülasyonu olan bir serviste çalışıyorum; yeni yatanlar, taburcu olanlar, postop hastalar. Hatta hafta sonu gündüz çalıştığımda servisteki hastalarımıza ek olarak günübirlik cerrahi için gelen hastalar da bu serviste oluyor. Hepsine yetemiyorsunuz." (Hemşire 3)

ifadesi ile gerekli bakımı verememelerinin altında yatan sistemsel nedenlere dikkat çekmiştir.

\section{Alt tema 2. Bireysel nedenler}

Hemşirelerin yetersiz mesleki bilgi ve beceri, mesleki değişiklikleri takip edememe, olaylara duygusal yaklaşma ve sorunlarla baş edememe nedenleri ile kendilerini iyi bir hemşire olarak görmedikleri belirlenmiştir. Bu konudaki bazı hemşire görüşleri şu şekildedir:

"Bu meslekte sürekli her şey değişiyor. Bilgiler, uygulamalar. Bunları takip edemiyorum. O yüzden kendimi yetersiz hissediyorum. Serviste yüksek lisans yapan arkadaşlar var. Onlardan yeni şeyler duydukça iyi oluyor aslında" (Hemşire 5)

" Duygusal davranmamın olumsuz bir özelliğim olduğunu düşünüyorum. Yeterince bilgili olmayabilirim ve istediğim ölçüde becerikli değilim." (Hemşire 9)

\section{Ana Tema 4. Hastalara Göre İyi Hemşire Özellikleri}

Hastalara göre iyi hemşire özellikleri dört alt temada toplanmıştır.

\section{Alt tema 1. İletişim}

Hastalar iletişim boyutunda, kendileri ile iyi iletişim kuran, ilgilenen, sorularını yanıtlayan ve gerekli bilgileri veren hemşirelerin iyi bir hemşire olduğunu belirtmişlerdir. Hastaların bu konuda bazı hasta ifadeleri şu şekildedir:

"Hastasına iyi bakan hemşiredir. Hastasının hal hatırını sorandır. Güler yüzlü olan, hastası ile iyi iletişime giren hemşiredir... Sadece ilaç veren değil aynı zamanda güler yüz ile bize zaman ayırıp iletişime giren." (Hasta 4)

“...Hastasının sorularına cevap verecek." (Hasta 2)

"Çalıştığı birim ile ilgili bilgili olmalı ve hastayı da bilgilendirmesi gerekir." (Hasta 6)

\section{Alt tema 2. Mesleki yetkinlik}

Hastalar mesleki yetkinlik boyutunda iyi bir hemşirenin iyi bir mesleki bilgiye sahip olan, gereken zamanda ve hastasına uygun bakım veren, uygulamaları sırasında acı vermeyen ve psikolojik destek sağlayan hemşireler olduğunu belirtmiştir. Hastaların bu konuda bazı hasta ifadeleri şu şekildedir:

"Kan alırken falan canımızı yakmayan, eli hafif hemşire" (Hasta 8)

"Verilmesi gereken şeyleri zamanında veren, takibini zamanında yapan hemşire." (Hasta 5) 
"Görevi olmadığı zaman da hastasının yanına gidip onu kontrol edebilen hemşire iyi bir hemşire olabilir bence. Hem hastayı psikolojik açıdan rahatlatabilecek zamanı da ayırır." (Hasta

1)

\section{Alt tema 3. Mesleği sevme}

Hastalar iyi bir hemşirenin mesleğini seven ve severek yapan hemşireler olduğuna dikkat çekmiştir. Bir hemşire bu konudaki görüşünü;

"Mesleğini seven hemşiredir. Mesleğini seven hemşire mesleğini de iyi yapar, iyi bir hemşire de olur." (Hasta 3)

şeklinde belirtmiştir.

\section{Alt tema 4. Kişilik özellikleri}

Hastalara göre iyi bir hemşirenin güler yüzlü, sabırlı, güvenilir ve kendine güvenen hemşireler olduğu belirlenmiştir. Bu konudaki bazı hasta görüşleri aşağıda verilmiştir.

"Iyi bir hemşire hastası ile iletişime giren, güler yüzlü hemşiredir." (Hasta 4)

"İyi hemşirenin sabırlı da olması gerekiyor. Özellikle acısı, ağrısı olan hastalara karşı." (Hasta 6)

"Iyi bir hemşire hastanın güvenini kazanabilir. Biz hastalar olarak hemşirelere çok güveniyoruz." (Hasta 1)

"Bir de iyi bir hemşire özgüvenlidir, kendine güvenir, yaptıklarına güvenir." (Hasta 8)

\section{Tartışma}

\section{Hemşirelere Göre İyi Hemşire Özellikleri}

Çalışmamızda iyi bir hemşirenin mesleği ile ilgili yenilikleri takip ettiği ve uyguladığı, öğrenmeye istekli ve alıcı olduğu, değişikliklere açık ve araştırmacı olduğu belirtilmiştir. Çalışmamıza benzer olarak niteliksel bir çalışmada iyi hemşirelerin, kanıta dayalı uygulamaları araştıran, takip eden ve uygulayan inovatif hemşireler olduğu belirlenmiştir. ${ }^{1}$ Hemşirelik öğrencileri ile yapılan bir çalışmada, öğrenciler hemşirelerde bulunması gereken özelliklerden birinin sürekli kendini geliştirme olduğunu belirtmiştir. ${ }^{10}$

Çalışmamızda hemşireler, iyi bir hemşirenin yeterli düzeyde mesleki bilgiye sahip olduğuna dikkat çekmiştir. Smith ve Godfrey'in çalışmasında, iyi bir hemşirenin iyi bir bilgi temelinin olması gerektiği vurgulanmıştır. ${ }^{8}$ Yapılan bir çalışmada ise sadece bilgi veya deneyimin iyi bir hemşire olmak için yeterli olmadığı, sahip olunan mesleki bilgiyi sürekli geliştirmenin ve paylaşmanın da gerektiği belirtilmiştir. ${ }^{7}$ ìyi bir hemşirenin sahip olması beklenen iyi düzeyde mesleki bilgi, hasta ile hemşire arasındaki güven duygusunu destekleyecektir. ${ }^{1}$

Çalışmamızda hemşireler mesleki yetkinlik kapsamında iyi bir hemşirenin hasta gereksinimlerine ve isteklerine duyarlı, zamanında, hasta merkezli ve bütüncül bakım veren hemşireler olduğunu belirtmiştir. Lee ve Kim'in hemşire ve hastalara göre iyi hemşire özellikleri ile ilgili çalışmaları inceledikleri çalışmada, profesyonel yaklaşım ve hasta merkezli bakım iyi hemşireler için temel mesleki yeterliliklerden biri olarak belirtilmiştir. ${ }^{2}$ Bireyselleştirilmiş bakım veren hemşireler, hastalarının eşsiz birer birey olduklarının farkındadırlar ve bakım uygulamalarını bireylerin tüm boyutlarını dikkate alarak hastaları ile beraber gerçekleştirirler. ${ }^{11}$

Sağlık bakım sisteminde hemşire hasta arasında etkili bir iletişim için empati önemlidir. ${ }^{12}$ Çalışmamızda iyi hemşirelerin iyi iletişim ve empati becerilerine sahip olduğu belirtilmiştir. Literatürde hastaların, hemşirelerin, akademisyenlerin ve öğrenci hemşirelerin iyi hemşireye ilişkin belirttikleri özelliklerden biri de 
iletişim becerisidir. ${ }^{1,68,8,13-15}$ Yapılan bir çalışmada hasta ile hemşire arasındaki etkili iletişimin hasta sonuçlarını olumlu etkilediği vurgulanmıştır. ${ }^{16}$ Mükemmel hemşirenin özelliklerine ilişkin hemşire görüşlerini belirlemek amacıyla yapılan nitel bir çalışmada, mükemmel hemşirenin her zaman iyi bir iletişim becerisine sahip olduğu ve en stresli durumlarda dahi empati yapabildiği belirtilmiştir. ${ }^{1}$ Hasta ve hemşirelerin etkin palyatif bakım uygulamalarına ilişkin algılarını belirlemek amacıyla yapılan bir çalışmada, hasta ve hemşireler tarafından belirtilen en önemli özelliklerden biri kişilerarası iletişim becerisidir. ${ }^{17}$ Günümüzde hasta, hemşire ve sağlık bakım ekibinin diğer üyeleri arasındaki iletişim problemlerinin hasta güvenliğini tehdit ettiği düşünüldüğünde, hemşirelerin bu özelliklere sahip olduklarını düşünmeleri önemlidir.

Çalışmamızda hemşireler iyi hemşirelerin mesleği sevme, mesleki bilinç ve sorumluluk sahibi olma özelliğini vurgulamıştır. Hemşire eğitmenlerinin iyi hemşireye ilişkin görüşlerini belirlemek amacıyla yapılan çalışmada, iyi hemşirelerin görevlerinin bilincinde olduğu görüşü belirlenmiştir. ${ }^{14}$ Andsoy ve ark.'nın çalışmasında, hemşirelik öğrencileri işinin öneminin bilincinde ve sorumluluk sahibi olmanın, mesleğini sevmenin ve işini iyi bilmenin hemşirelerde bulunması gereken özellikler olduğunu belirtmişlerdir. ${ }^{10}$ Hemşirelerin mesleği sevmesi, bakım kalitesine katkı sağlayacaktır.

Smith ve Godfrey'in çalışmasında hemşireler iyi hemşirenin mesleki özelliklerinin yanı sıra kişisel özellikleri üzerinde de durmuştur. ${ }^{8}$ Hemşire eğiticiler ile yapılan bir çalışmada iyi bir hemşire hasta bireyselliğine saygı duyan ve hastalara birey olarak değer veren hemşireler olarak nitelendirilmiştir. ${ }^{14}$ Lee ve Kim hasta ve hemşirelerin iyi hemşire algıları ile ilişkili 11 çalışmayı inceledikleri çalışmada, saygılı, insancıl, destekleyici ve sadık olma en sık tanımlanan kişilik özellikleri olarak belirlenmiştir. ${ }^{2}$ Literatüre paralel olarak çalışmamızda hemşirelerin iyi bir hemşirenin bazı insancıl özellikler taşıdıklarına ilişkin görüşleri belirlenmiştir. Hemşireler iyi bir hemşirenin merhametli, vicdanlı, güvenilir, sabırlı, saygılı, hoşgörülü, ahlaklı, önyargısız, hümanist ve içinde insan sevgisi olan hemşireler olduğunu belirtmiştir. Bakım uygulamaları hastalara içten sevgi gösterilerek ve insan onuru, biricikliği ve değerini göz önüne alarak yapılması gereken uygulamalardır. ${ }^{18}$ Çalışmamızda belirlenen insancıl özellikler hemşirelerin hastalara sadece insan olmalarından ötürü hak ettikleri bakımı almalarını sağlayan özelliklerdir. Çalışmamızda hemşireler iyi bir hemşirenin aynı zamanda prensipli, planlı, düzenli, dikkatli, disiplinli ve kuralcı olduğunu belirtmiştir. Hemşirelik öğrencileri hemşirelerin hızlı, çalışkan ve disiplinli olması gerektiğini; hemşire eğitmenleri iyi hemşirelerin kurallara saygı gösterdiklerini belirtmiştir. ${ }^{10,14}$ Bu kişilik özelliklerinin mesleki yaşama yansıması bakımın daha planlı verilmesini sağlayacaktır.

Hemşirelerin idealize ettikleri ve kendilerinin sahip olduklarını düşündükleri iyi hemşire özelliklerinin çoğunlukla benzer olduğu belirlenmiştir. Çalışmamızda hemşirelerin iyi bir hemşireye ilişkin ifade ettikleri niteliklerin çoğunlukla hemşireliğin bağımsız bir disiplin olabilmesi ve mesleki profesyonelleşme için gerekli özellikler olduğu söylenebilir. Hemşireler tarafından iyi bir hemşirede olması gerektiği belirtilen çoğu özelliğin her hemşirenin sahip olması gereken özellik olduğu söylenebilir.

\section{Hemşirelerin Kendilerini İyi Hemşire Olarak Görmeme Nedenleri}

Hemşirelerin çeşitli sistemsel ve bireysel faktörler nedeni ile kendilerini iyi bir hemşire olarak görmedikleri belirlenmiştir. Hemşirelerin hemşire sayısının yetersiz, iş yükünün ve hasta sayısının fazla olması nedeni ile hastalarına etkin ve istendik bakım veremedikleri belirlenmiştir. Literatürde yetersiz hemşire istihdamının malpraktis ve basınç ülseri, hastane enfeksiyonları, düşmeler gibi hasta güvenliğini tehdit eden istenmeyen durumlar ile ilişkili olduğu belirtilmektedir. ${ }^{19,20}$ Olumsuz çalışma koşulları hemşireliğin profesyonelleşme sürecini olumsuz etkilemekte ve hemşirelerin bireyselleştirilmiş bakım vermelerini zorlaştırmaktadır. ${ }^{21,22}$ Bireyselleştirilmiş bakım hastaların memnuniyetini, yaşam kalitesini, fiziksel ve psikolojik sağlığını arttırmaktadır. Ayrıca verilen bakımın olumlu sonuçlarını gören hemşirelerin iş doyumu artmaktadır. ${ }^{18}$ 
Yapılan çalışmalarda hemşirelerin hasta bakımı dışında telefonları yanıtlama, ilaç ve malzeme temini, giriş çıkışları kontrol gibi uygulamalara daha çok zaman harcadıkları belirlenmiştir. ${ }^{23,24}$ iş yükünü arttıran ve hemşirelik bakımına ayrılan zamanın azalmasına neden olan bu uygulamalar, iş doyumunda azalma ve tükenmişliği de beraberinde getirmektedir. ${ }^{21,22}$

Sağlık sisteminde yaşanan sorunlar hemşirelerin duygularının farkında olabilen ve duygularını yönetebilen bir başka ifade ile duygusal zekâları gelişmiş bireyler olmalarını gerektirmektedir. ${ }^{25}$ Hemşirelikte gelişmiş duygusal zeka, hemşirelerin öncelikle kendilerinin daha sonra diğer bireylerin duygularını anlayabilmesini ve bu duyguları yönetebilmesini sağlar. ${ }^{26}$ Çalışmada hemşireler olaylara duygusal yaklaşmalarının iyi bir hemşire olmalarını engelleyen olumsuz özellikleri olduğunu belirtmiştir. Olaylara duygusal yaklaşmanın olumsuz bir özellik olmadığı, hemşirelerin olaylara ve duygulara karşı duyarlıı̆ının bir göstergesi olduğu söylenebilir. Duygusal zekası gelişmiş hemşireler, kritik durumlarda doğru kararlar verebilir ve hastalar ile etkili iletişim kurarak hasta memnuniyetini arttırabilir. ${ }^{26}$

Bu çalışmada hemşirelerin sorunlar ile baş edemediklerini düşünmeleri kendilerini iyi bir hemşire olarak görmemelerine neden olan bir diğer bireysel faktör olarak belirlenmiştir. Hemşirelerin stresle baş etme yöntemlerinin belirlenmesi ve olumlu baş etme davranışlarının geliştirilmesinin iş doyumunun arttırılması, fiziksel ve psikolojik sağlığın korunması, tükenmişliğin ve işten ayrılmaların azaltılması açısından önemli olduğu düşünülmektedir. ${ }^{27}$

\section{Hastalara Göre İyi Hemşire Özellikleri}

Hemşirelerin mesleki bilgi ve becerileri ile birlikte iyi kişilik özelliklerine de sahip olmaları beklenmektedir. ${ }^{5}$ Çalışmamızda da hastalar iyi bir hemşirenin bazı kişilik özelliklerini belirtmişlerdir. Bu özellikler özgüven, güler yüz ve sabırdır. Hemşirelerin özgüvenli olmaları, profesyonel benlik kavramı üzerinde ve klinik karar vermede pozitif bir etkiye sahip olacaktır. ${ }^{28,29}$ Hastaların nitelikli hemşirelik bakımından beklentilerini inceleyen çalışmalarda, hastaların hemşirelerden güler yüzlü, hoşgörülü, iyi niyetli, insancıl, ilgili, sabırlı, saygılı, fedakâr, samimi, dürüst ve arkadaş canlısı olmalarını ve kendilerine değer vermelerini bekledikleri belirlenmiştir. ${ }^{13,21}$ Kanser hastaları ile yapılan bir çalışmada hastalar, hemşireleri önemli, rahatlatan, ilgi gösteren, anlayış sahibi, duyarlı, yardımsever ve empati kurabilen bireyler olarak belirtmişlerdir. ${ }^{30}$ Hastalar iyi bir hemşirenin onlara şefkat göstererek iyileşme sürecini kolaylaştırdığını belirtmiştir. ${ }^{13}$ Çalışmamızda ve literatürde belirtilen bu kişilik özelliklerine sahip hemşirelerin, hastalara insancıl yaklaşımları hastaların öz saygılarının korunması ve insan olarak kendilerini değerli hissetmeleri açısından önemlidir.

Çalışmamızda hastalar kendileri ile ilgilenen, sorularını yanıtlayan, kendileri ile iyi iletişim kuran hemşirelerin iyi hemşireler olduklarını belirtmiştir. Yapılan bir çalışmada kanser hastalarının iyi hemşireleri hastalara saygı duyan ve destek sağlayan ilişkiler kuran hemşireler olarak nitelendirdikleri belirlenmiştir. ${ }^{13}$ Çocuk hastalar iyi bir hemşirenin onları dinleyen ve onlarla vakit geçirmeye istekli hemşireler olduğunu belirtmişlerdir. ${ }^{6} \mathrm{Bu}$ çalışma bulgumuz, hastaların hemşireler ile iletişim içinde olma gereksinimini göstermektedir.

Çalışmamızda hastalar tedavisini zamanında uygulayan, uygulamaları sırasında acı vermeyen, iyi düzeyde mesleki bilgisi olan ve psikolojik destek sağlayan hemşirelerin iyi hemşire olduklarını belirtmişlerdir. Hastalar iyi hemşirelerin mesleki becerilerinin yanı sıra hemşirelik ve hemşirelik dışı bilgilere sahip olan, ihtiyaçlarını değerlendiren ve karşılayan, hastalığını, tedavisini ve semptomlarını takip eden, kendileri tarafından bile fark edilmeyebilecek değişiklikleri veya intiyaçları fark edebilecek düzeyde duyarlı hemşireleri iyi hemşire olarak belirtmiştir. ${ }^{31-33}$ Hastaların nitelikli hemşirelik bakımından beklentilerini inceleyen bir çalışmada, hastaların hemşirelerden profesyonel bilgi ve beceriye sahip olmalarını, tedaviyi ve bakımı zamanında ve tam yapmaların bekledikleri belirlenmiştir. ${ }^{19}$ Acil hastalarının bakım gereksinimlerinin 
belirlendiği bir çalışmada hastalar uygulamalarda yetkin hemşirelerden hızlı ve duyarlı bakım alma isteklerini belirtmişlerdir. ${ }^{34}$

\section{Sonuç}

Hastaların ve hemşirelerin iyi hemşire algılarını değerlendirdiğimiz bu çalışmada, hemşireler tarafından belirtilen iyi hemşire özellikleri, gelişime ve değişime açıklık, mesleki yetkinlik, iletişim, mesleki bilinç ve sevgi ile kişilik özellikleri kategorilerinden; hastalar tarafından belirtilen iyi hemşire özellikleri iletişim, mesleki yetkinlik, mesleği sevme ve kişilik özellikleri kategorilerinden oluşmuştur. Hemşirelerin bazı bireysel ve sistemsel kökenli faktörler nedeniyle kendilerini iyi bir hemşire olarak görmediklerini belirlenmiştir. Hemşireler ve hastalar tarafından belirtilen iyi hemşire özelliklerinin benzer ve aslında mesleki eğitim sonucunda her hemşirenin sahip olması gereken özellikler olduğu dikkat çekmektedir. Çalışma sonuçlarımızın klinik ortamda hemşirelerin kendilerini ve hemşire yöneticilerin hemşireleri iyi bir hemşire olma açısından değerlendirmelerinde; eğitim ortamlarında öğrencilerin mesleki kimliklerini geliştirmelerinde yardımcı olabileceği düşünülmektedir. Bu sonuçlar doğrultusunda, iyi hemşire niteliklerini belirlemeye yönelik daha fazla araştırma yapılması ve hemşirelerin iyi bir hemşire olmalarını engelleyen faktörlerin iyileştirilmesine yönelik planlamalar yapılması önerilmektedir.

\section{Bilgi}

Yazarlar arasında çıkar çatışması bulunmamaktadır. Bu çalışma için herhangi bir finansal destek alınmamıştır.

\section{Etik Onay}

Çukurova Üniversitesi Tıp Fakültesi Girişimsel Olmayan Klinik Araştırmalar Etik kurulu (14 Şubat 2020 tarih, 96/89 karar no)

\section{Araştırmacı Katkı Oranı Beyanı}

İpek Köse Tosunöz: Fikir, tasarım, denetleme, veri toplama ve işleme, analiz ve yorum, kaynak taraması, makale yazımı, eleştirel inceleme.

Meltem Akbaş: Fikir, tasarım, denetleme, veri toplama ve işleme, analiz ve yorum, kaynak taraması, makale yazımı, eleştirel inceleme.

Gürsel Öztunç: Fikir, tasarım, denetleme, kaynak taraması, makale yazımı, eleştirel inceleme.

\section{Kaynaklar}

1. Paans W, et al. What establishes an excellent nurse? A focus group and Delphi panel approach. BMC Nursing 2017; 16: 45. doi: 10.1186/s12912-017-0239-x

2. Lee K, Kim SH. What is the 'Good Nurse'?: An Integrative Literature Review. Medico-Legal Update 2019; 19(1): 743-748.

3. Göriş S, et al. Hemşirelerin profesyonel değerleri ve etkileyen faktörler. Psikiyatri Hemşireliği Dergisi 2014; 5(3): 137-142. doi: 10.5505/phd.2014.74046

4. Taylan S, Alan S, Kadıoğlu S. Hemşirelik Rolleri ve Özerklik. HEMAR-G 2012;14: 66-74.

5. Zhang L, et al. The personality profile of excellent nurses in China: the 16PF. Contemporary Nurse 2013; 43: 219-24. doi: 10.5172/conu.2013.43.2.219.

6. Brady M. Hospitalized children's views of the good nurse. Nursing Ethics 2009; 16: 543-60. doi: 10.1177/0969733009106648.

7. Al-Hussami M, et al. Patients' perception of the quality of nursing care and related hospital services. Health and Primary Care 2017; 1:1-6. doi: 10.15761/HPC.1000110

8. Smith KV, Godfrey NS. Being a good nurse and doing the right thing: A qualitative study. Nursing Ethics 2002; 9: 301-312. doi: 10.1191/0969733002ne512oa

9. Yıldırım A, Şimşek H. Qualitative research methods in social sciences. Ankara: Seçkin Publications; 2016.

10. Andsoy II, Güngör T, Bayburtluoğlu T. Karabük Üniversitesi Sağlık Yüksekokulu öğrencilerinin hemşireliği tercih etme nedenleri ve mesleğin geleceği ile ilgili görüşleri. Balıkesir Sağlık Bilimleri Dergisi 2012; 1(3): 124-130. doi: 10.5505/bsbd.2012.87597

11. Rortveit $\mathrm{K}$, et al. Patients' experiences of trust in the patient nurse relationship-A systematic review of qualitative studies. Open Journal of Nursing 2015; 5: 195-209. doi: 10.4236/ojn.2015.53024 
12. Ding $X$, et al. Effectiveness of empathy clinical education for children's nursing students: A quasi-experimental study. Nurse Educ Today 2020; 85: 104260. doi: 10.1016/j.nedt.2019.104260.

13. Rchaidia L, et al. Cancer patients' perceptions of the good nurse: a literature review. Nurs Ethics 2009;16: 528-42. doi: 10.1177/0969733009106647.

14. De Araujo Sartorio N, Pavone Zoboli ELC. Images of a 'good nurse' presented by teaching staff. Nurs Ethics 2010; 17(6): 687694.

15. Han D. Images of good nurses as perceived by nursing college students: A Q-Methodological approach. J Korean Acad Nurs Educ. 2018; 24(1): 61-71.

16. Kourkouta L, Papathanasiou IV. Communication in nursing practice. Materi sociomed 2014; 26(1): 65. doi: 10.5455/msm.2014.26.65-67

17. Johnston BM, Smith LN. Nurses'and patients'perceptions of expert palliative care. J Adv Nurs 2006; 54(6): 700-9. doi: 10.1111/j.1365-2648.2006.03857.x

18. Toru F. Hemşirelik uygulamalarının kilit noktası: bireyselleştirilmiş bakım. Adnan Menderes Üniversitesi Sağılk Bilimleri Fakültesi Dergisi 2020; 4(1): 46-59.

19. Türkmen E. Hemşire istihdamının hasta ve hemşire sonuçları ile organizasyonel çıktılara etkisi: Yataklı tedavi kurumlarında hemşire insan gücünü planlama. Hacettepe Üniversitesi Hemşirelik Fakültesi Dergisi 2015; 2(3): 69-80.

20. Bal Demirgöz, M. Yataklı tedavi kurumlarında hemşire insangücü planlama yaklaşımları. Sağlık ve Hemşirelik Yönetimi Dergisi 2014; 3(1): 148-154. doi:10.5222/SHYD.2014.148

21. Gül Ş, Dinç L. Hastaların ve hemşirelerin hemşirelik bakımına yönelik algılarının incelenmesi. HUHEMFAD 2018; 5(3): $192-208$.

22. Burtson P, Stichler J. Nursing work environment and nurse caring: relationship among motivational factors. J Adv Nurs 2010; 66(8): 1819-1831.

23. Pelzang R. Time to learn: understanding patient-centred care. $\mathrm{Br} J$ Nurs 2010; 19 : $912-917$. doi: 10.12968/bjon.2010.19.14.49050

24. Karayurt Ö, Ursavaş FE, İşeri Ö. Hemşirelerin bireyselleştirilmiş bakım verme durumlarının ve görüşlerinin incelenmesi. ACU Sağlık Bil Derg 2018; 9(2): 163-169.

25. Kuşaklı BY, Bahçecik N. Yönetici hemşirelerin duygusal zeka yetenekleri ve liderlik davranışları. i.Ü.F.N. Hem. Derg 2012; 20(2): 112-119.

26. Okumuş Çolak D, Uğur E. Hemşirelerin duygusal zeka düzeylerinin bakım davranışlarına etkisi. Acıbadem Üniversitesi Sağlık Bilimleri Dergisi 2017, 8(2): 104-109.

27. Mert Boğa S ve ark. Hemşirelik bakımını olumsuz etkileyen etmenler ile hemşirelerin stresle başa çıkma yöntemleri arasındaki ilişkinin incelenmesi. Türkiye Klinikleri Sağlık Bilimleri Dergisi 2019; 4(3): 251-260.

28. Öner H, Koruklu N, Küçükoğlu NC. Hemşirelik öğrencilerinin profesyonel benlik kavramını yordayan değişkenler: özgüven ve sosyal sorun çözme becerisi. Medical Sciences 2019; 14(4): 194-204.

29. White KA. Development and validation of a tool to measure self-confidence and anxiety in nursing students during clinical decision making. J Nurs Educ 2013; 53(1): 14-22. doi: 10.3928/01484834-20131118-05

30. Radwin L, et al. Cancer patients' descriptions of their nursing care. J Adv Nurs 2005; 50: 162-169. doi: 10.1111/j.13652648.2005.03375.x.

31. Izumi S, et al. Japanese patients' descriptions of "The Good Nurse": personal involvement and professionalism. ANS Adv Nurs Sci 2006; 29(2): E14-E26. doi: 10.1097/00012272-200604000-00013

32. Kim GU, et al. Revisiting the meaning of a good nurse. The Open Nursing Journal 2019; 13(1). doi: $10.2174 / 1874434601913010075$

33. Liu J, Mok E, Wong T. Caring in nursing: investigating the meaning of caring from the perspective of cancer patients in Beijing, China. J Clin Nurs 2005; 15: 188-96. doi: 10.1111/j.1365-2702.2006.01291.x.

34. Suroso J, et al. Top ten caring needs of emergency department patients in Banyumas, Central Java province, Indonesia; patient's needs and cultural approach. IJRMS 2015; 3(1): S61-68. doi: 10.18203/2320-6012.ijrms201515226-62. 